Egyptian Journal of Aquatic Biology \& Fisheries

Zoology Department, Faculty of Science,

Ain Shams University, Cairo, Egypt.

ISSN $1110-6131$

Vol. 24(5): 639 - 660 (2020)

www.ejabf.journals.ekb.eg

\title{
Association Between the Distributions and Chemical Composition of Aquatic \\ Macrophytes and Bacterial Community Structure in Some Irrigation Canals (Rayahs) of the Nile River, Egypt
}

\author{
Amal A. Othman and Amany M. Haroon* \\ National Institute of Oceanography and Fisheries (NIOF), 11516 Cairo, Egypt \\ *Corresponding Author: amanyharoon30@yahoo.com
}

\section{ARTICLE INFO}

Article History:

Received: June 25, 2020

Accepted: Aug. 20, 2020

Online: Aug. 23, 2020

Keywords:

Nile River Rayahs;

Macrophytes,

Chemical composition;

Macro-element;

Bacterial

indicator of pollution;

Diazotrophs

\begin{abstract}
Variations in distribution, species composition, and chemical constituents of aquatic macrophytes of Al-Rayah El Tawfiky (T) and Al-Rayah El Monoufy (M) in addition to their relations with bacterial communities structure and water variables were studied over the period from spring 2014 to winter 2015. Ten of the aquatic macrophytes species related to 7 families and 9 genera were recorded. Myriophyllum spicatum was the most dominant species, the autumn season and Al-Rayah (M) were the richest in species numbers. Protein, lipid, nitrogen, phosphorus, and potassium were detected at higher concentrations in Ceratophyllum demersum from Al-Rayah (T), however organic matter and nitrogen-free extracts contents attended their highest values in Potamogeton nodosus from Al-Rayah (M).

Microbial analyses indicated the presence of total bacterial counts and the total diazotrophs in high population densities (Up to $10^{5}$ ). However, total and fecal coliforms populations are exceeding the permissible limits cited by World Health Organization, recorded their highest numbers in spring at the site of Al Rayah (M) which was occupied by Potamogeton nodose and Myriophyllum spicatum. A significant difference in chemical composition, distribution pattern, the community structure of aquatic macrophytes, and bacteria attributed to the seasons and site differences, in addition to the nutritional potential of the analyzed macrophytes species especially submerged ones were recorded.
\end{abstract}

\section{INTRODUCTION}

Water is the most important natural source for life, being essential for humans and indispensable for all ecosystems (WHO 2011). Surface water in the Nile Delta is of vital importance for domestic, agricultural, and industrial water supply. At Delta Barrage, the Nile River bifurcates into two main branches namely Damietta and Rosetta and four subbranches (Rayah).

Al Rayah El- Tawfiky and Al Rayah-El Monoufy are two sub-branches canals of

Nile River, which divert water to the Estern and Middle Delta. In recent years the 
increases in population together with the agricultural and industrial development have resulted in increasing pollution of water resources that affect life of macrophytes plants and bacterial communities of aquatic system.

Aquatic weeds are unwanted plants grow naturally in lakes, ponds and other water bodies. They are primary producers that have many ecosystem services, like: structure and functioning of aquatic ecosystems (Zhi et al. 2015), improving of water quality (Zhang et al. 2016), considered as a base of aquatic food-chains and as good source of food and fodder for humans, aquatic herbivores, fishes and farm animals (Sharshar and Haroon, 2009) and as a source of biologically active substances (Daboor and Haroon, 2012; Haroon and Abdel-Aal, 2016; Haroon and Daboor, 2019). In contrast, they can cause many ecological losses by adversely affecting, irrigation, navigation, public health as well as the fish production.

The quality of water is typically determined by monitoring bacterial presence especially feacal coliform bacteria, which are used as microbiological indicator of the pollution. Bacteria are the major users of dissolved organic matter and therefore of central importance for carbon cycle in aquatic systems (They and Marques, 2019). The availability of fixed inorganic nitrogen often plays a fundamental role in regulating primary production in both aquatic and terrestrial ecosystems. Because biological nitrogen fixation is an important source of nitrogen in waters, particularly if those are to be used for irrigating agricultural lands, the study of $\mathrm{N}_{2}$-fixing microorganisms is of special concern to our understanding of global nitrogen cycle. Vast array of work has been done on the occurrence and activity of diazotrophs in Egyptian aquatic systems (Othman and Sabae, 2013 and Othman et al. 2016) and in aquatic world (Jabir et al. 2020).

The distribution of aquatic plants and microbial species largely depend up on the nutrient status of freshwaters (Srivastava et al. 2017 and Haroon, 2020 a). In addition, aquatic macrophytes can affect the structure and function of bacterial community in aquatic environment, by releasing allelochemicals substances that inhibit bacteria both directly and indirectly, the latter via inhibition of algae (El-Sheekh et al. 2017). Therefore, the studying of the factors affecting their distribution and biochemical composition is of paramount important for managing them in useful purposes.

In this study we assessed the seasonal and spatial variations in aquatic macrophytes distribution, community structure and chemical composition of both submerged and floating macrophytes species. In addition, this study has marked structures in bacterial communities which were correlated with various abiotic (seasons, sites and water characteristics of sampling sites) and biotic factors (presence and type of macrophyte) of two different water bodies (Al-Rayah El Tawfiky (T) and Al-Rayah El Monoufy (M)). 


\section{MATERIALS AND METHODS}

\section{Study area:}

Seven sampling sites were selected for each Rayah in addition to one sample before bifurcation of the River Nile $(\mathrm{RN})$ as a control sample for two Rayahs (Figure 1\&Table 1).

\section{Plant sampling and preparation:}

Different macrophytes life forms were collected seasonally during the period of spring 2014 to winter 2015 from the selected sites. At each site, macrophytes samples were collected by hand, removal to the laboratory, where they were separated into different taxa, identified after Boulos (2005), cleaned, washed with water and dried in shade. A part of each plant species was dried at $50{ }^{\circ} \mathrm{C}$ to constant weight, ground to fine powder and stored for estimation of chemical constituents (Including, organic matter, ash, nitrogen free extracts, protein, lipid, nitrogen, potassium and phosphorus contents). The other part was dried separately at $100{ }^{\circ} \mathrm{C}$ to constant weight for dry matter determinations.

\section{Plant analysis:}

Only submerged and floating macrophytes samples were subjected to the biochemical analysis owing to their importance as a natural food resources for fishes. The plant extract was prepared using sulphuric acid and perchloric acid following Peter (Burgski, 1968). Different methods were used for estimation of total ash, protein, lipid, nitrogen, phosphorus, Nitrogen-free extracts (NFE) and potassium (Egyptian Pharmacopoeia, 1953; Ölberg, 1956; Blight and Dyer, 1959; Black, 1965; Snel and Snel 1967; Pádua et al. 2004 and Umoren et al. 2005 respectively).

\section{Water sampling and analysis:}

Water samples were aseptically collected in sterile brown bottles $(500 \mathrm{ml})$, stored at $4{ }^{0} \mathrm{C}$ until chemical and bacteriological analysis that completed within $48 \mathrm{~h}$ of sampling. In the laboratory, Chemical parameters (Including, $\mathrm{pH}$ value, Total nitrogen $(\mathrm{TN})$, Total phosphorus $\left(\mathrm{PO}_{4}\right)$, Electrical conductivity (EC), Dissolved oxygen (DO), Biochemical oxygen demand (BOD), Chemical oxygen demand (COD), Nitrite $\left(\mathrm{NO}_{2}\right)$, Nitrate $\left(\mathrm{NO}_{3}\right)$ and Ammonium $\left(\mathrm{NH}_{4}\right)$ ) were assessed following APHA (2005) and authors used chemicals data from Goher (2015). Bacteriological analyses was assessed as described below.

\section{Bacteriological analysis:}

Autochthonous and allochthonous bacteria were enumerated on plate count agar medium (APHA, 2005) at 20 and $35^{\circ} \mathrm{C}$ incubation temperatures (Autochthonous and allochthonous, respectively). Most probable number (MPN) procedure was followed to determine total coliform (TC) and fecal coliform (FC) using LTB (Lauryl Tryptose Broth) (Lab M limited, UK) $\left(35^{\circ} \mathrm{C} \pm 0.5^{\circ} \mathrm{C}\right.$ at $24 \pm 2$ hours) for total coliform bacteria, EC Broth (Lab M limited, UK) $\left(44.5{ }^{\circ} \mathrm{C} \pm 0.2{ }^{\circ} \mathrm{C}\right.$ at $24 \pm 2$ hours) for feacal coliform bacteria and azide-dextrose broth (Lab M limited, UK) for fecal streptococci (APHA, 
2005). Total diazotrophs were enumerated using the surface inoculated plate method on $\mathrm{N}$-deficient combined carbon sources agar medium, CCM (Hegazi et al. 1998).

\section{Statistical analyses:}

One-way ANOVA was applied to assess the significance of variations in chemical composition of macrophytes in relation to the sites of the two water course and the season (SAS, 1985). Microbiology data were statistically analyzed using STATISTICA 10 (StatSoft Inc. 2011). In addition, data were examined with principal component analysis (PCA) in order to indicate the affecting of macrophytes and bacteria with the other abiotic variables, using XL Stat version 2017.

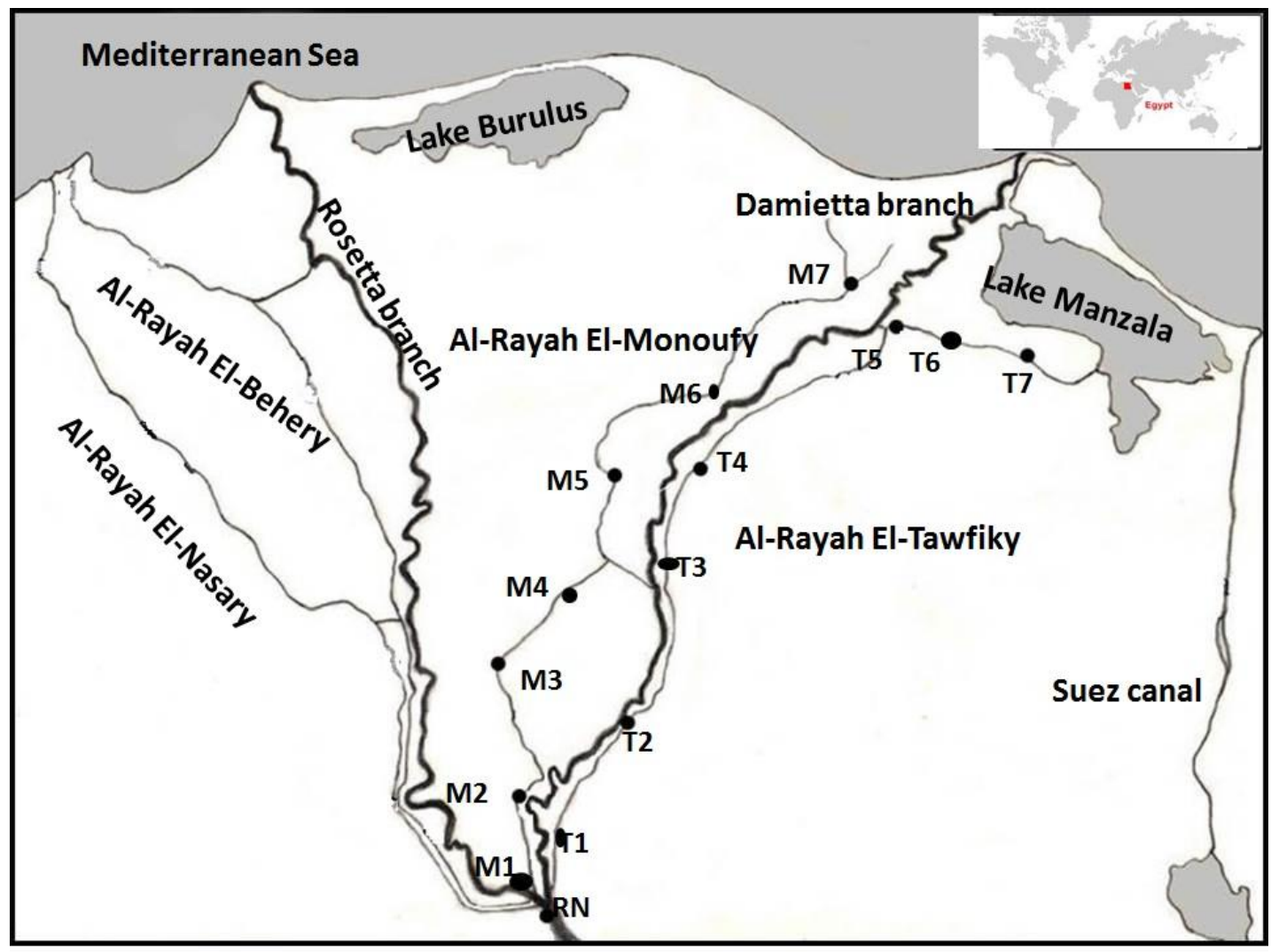

Fig. 1: Map of sampling sites along Al-Rayah El-Monoufy (M) and Al-Rayah El-Tawfiky (T) of the Nile River, Egypt 
Table 1: GPS data and description of sampling locations at Al-Rayah El-Tawfiky (T) and Al-Rayah El-Monoufy (M).

\begin{tabular}{|c|c|c|c|c|c|}
\hline $\begin{array}{l}\text { Sites } \\
\text { codes }\end{array}$ & Names & Latitude & Longitude & Distance from El Kanater & Description \\
\hline $\mathbf{R N}$ & River Nile & $30^{\circ} 10^{\prime} 20.72^{\prime \prime}$ & $31^{\circ} 8 ' 23.98 "$ & $1.5 \mathrm{~km}$ & Upstream El-El-Kanater \\
\hline T1 & El Kanater & $30^{\circ} 11^{\prime} 46.58 \prime \prime$ & $31^{\circ} 7^{\prime} 55.98 \prime \prime$ & $1-1.5 \mathrm{Km}$ & After railway station of EI Kanater EI Khairia \\
\hline $\mathbf{T 2}$ & Banha & $30^{\circ} 28 ' 24.0^{\prime \prime}$ & 31'12'1.04" & $40 \mathrm{Km}$ & In the Front of Banha Water plants \\
\hline T3 & Met gamer & $30^{\circ} 41 ' 35.3 \prime$ & $31^{\circ} 16^{\prime} 50.2^{\prime \prime}$ & $70 \mathrm{Km}$ & Between agricultural and residential regions \\
\hline T4 & Agga & $30^{\circ} 54^{\prime} 23.12^{\prime \prime}$ & $31^{\circ} 16 ' 51.88 "$ & $100 \mathrm{Km}$ & $\begin{array}{l}\text { There are agricultural and residential regions at the } \\
\text { two banks }\end{array}$ \\
\hline T5 & Mansoura & $31^{\circ} 04^{\prime} 02.84^{\prime \prime}$ & $31^{\circ} 25^{\prime} 02.13 \prime \prime$ & $130 \mathrm{Km}$ & Before bifurcation of El-Rayah \\
\hline T6 & Dekerness & $31^{\circ} 5^{\prime} 38.65^{\prime \prime}$ & $31^{\circ} 37^{\prime} 37.77^{\prime \prime}$ & $155 \mathrm{Km}$ & $\begin{array}{c}\text { Between residential region in the west side and } \\
\text { agricultural region in east side }\end{array}$ \\
\hline T7 & El-Manzalah & $31^{\circ} 09^{\prime} 49.9^{\prime \prime}$ & $31^{\circ} 56^{\prime} 09.5^{\prime \prime}$ & $185 \mathrm{Km}$ & End of El Rayah \\
\hline M1 & El Kanater & $30^{\circ} 11 ' 59.85 \prime \prime$ & $31^{\circ} 6^{\prime} 44.97 "$ & $1 \mathrm{Km}$ & Behind fish research station of NIOF \\
\hline M2 & El-Khadra & $30^{\circ} 20^{\prime} 15^{\prime \prime}$ & $31^{\circ} 02^{\prime} 55^{\prime \prime}$ & $30 \mathrm{Km}$ & Middle of agricultural and residential regions \\
\hline M3 & Shebeen El-Koum & $30^{\circ} 32^{\prime} 04.3^{\prime \prime}$ & $31^{\circ} 00^{\prime} 48.3^{\prime \prime}$ & $60 \mathrm{Km}$ & In Shebeen El-Koum City \\
\hline M4 & El-Santa & $30^{\circ} 43^{\prime} 44.50^{\prime \prime}$ & $31^{\circ} 7^{\prime} 28.88^{\prime \prime}$ & $100 \mathrm{Km}$ & In El Santa City \\
\hline M5 & Zifta & $30^{\circ} 47^{\prime} 26.15^{\prime \prime}$ & $31^{\circ} 9 ' 16.12 "$ & $130 \mathrm{Km}$ & Receives the water from Damietta branch \\
\hline M6 & El-Mahalla & $30^{\circ} 56^{\prime} 59.4^{\prime \prime}$ & $31^{\circ} 09^{\prime} 21.4^{\prime \prime}$ & $155 \mathrm{Km}$ & In El Mahalla City \\
\hline M7 & Belqas & $31^{\circ} 07^{\prime} 59.9^{\prime \prime}$ & $31^{\circ} 22^{\prime} 50.1^{\prime \prime}$ & $185 \mathrm{Km}$ & $\begin{array}{l}\text { Middle of agricultural regions and Before bifurcation } \\
\text { of El-Rayah to small branches }\end{array}$ \\
\hline
\end{tabular}

\section{RESULTS AND DISCUSSION}

\section{Floristic composition of the collected macrophytes samples.}

Aquatic macrophytes constitute an important components of many freshwater ecosystems, their distribution and community structure is largely controlled by different environmental factors such as, water and sediment chemistry, nutrient availability and allelopathic interaction with other aquatic organisms (Hansel-Welch et al. 2003 and Del Pozo et al. 2011). During the period of study ten macrophytes species representing the different macrophytes life forms, related to nine genera and seven families were recorded (Table 2). This number of species is lower than that recorded by previous researcher like: El-Amier et al. (2015, 2016), Haroon and Hussian (2017), Haroon (2020b); they recorded the presence of 70,18,12 and 11 of macrophytes species at Damietta branch, Rosetta Branch, Al Rayah El-Nasery and El-Noubaria Canal and Al- Rayah El Behery of the Nile River Egypt respectively.

The emergent macrophytes acquired a dominant position in the study area represent $60 \%$ of the total collected species, followed by submerged and floating species representing $20 \%$ for each of them. Throughout the study period Al Rayah El Monoufy showed the richest habitat in species number and autumn was the richest season (8 species). 


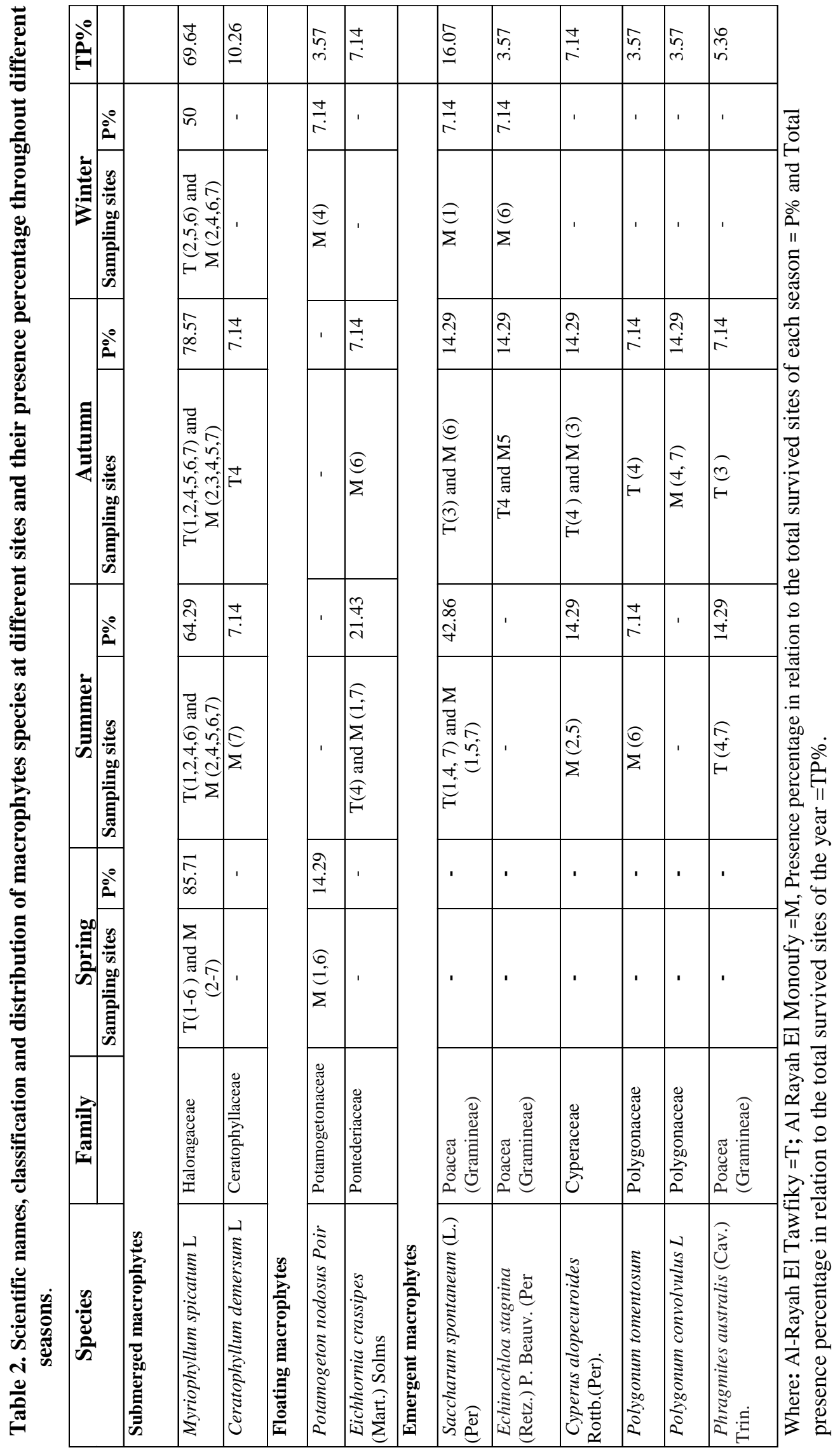


Seasonal and spatial variations in presence percentage of each macrophytes species was observed (Table 2). Among all the macrophytes recorded the submerged macrophyte species $M$ spicatum was found to be the most frequent species as it occurs in $85.71,64.29,78,57$ and $50 \%$ of the sampling sites during spring, summer, autumn and winter respectively. During summer it was followed in presence percentage by $S$. spontanium (42.86\%) and E. crassipes $21.43 \%$. (Table 2). However, during autumn it was followed in presence percentage by S. spontanum, E. stagnin and C. alopecuroides Rottb. (Per). Only four macrophytes species were recorded during winter, in which $M$. spicatum was the only recorded species at Al-Rayah El Tawofiky, however at Al- Rayah El Monoufy it was found associated with the floating macrophyte species $P$. nodosus and with the two emergent species $S$. spontanium and E. stagnina.

\section{Biochemical analysis of the selected macrophytes}

Variations in nutritional components in relation to plant species, season and sampling site were observed (Table 3). In general, both floating and submerged macrophytes were characterized by their high water content, which is usually a major deterrent to their harvest and utilization (Edward, 1980). The water content of the macrophytes listed ranged between $88.72 \pm 1.24$ and $94.12 \pm 1.02 \%$ of wet wt with the highest for autumn samples. As shown in results (Table 3) the mean seasonal values of ash and organic matter contents varied significantly $(\mathrm{P}<0.05)$ between different seasons, species and sampling sites, with the lowest ash and highest organic matter contents for winter sample of the floating macrophyte species $P$. nodosus from Al Rayah El Monoufy (8.67 \pm 0.02 and $91.33 \pm 0.02 \% \mathrm{DW}$ respectively).

In the two studied canals the nitrogen free extracts (NFE) constitutes the major part of the macrophytes biochemical composition, ranged from $59.40 \pm 0.23 \% \mathrm{DW}$ for autumn samples of $C$. demersum from Al-Rayah El Tawofiky to $78.57 \pm 0.00 \%$ DW for winter samples of $P$. nodosus from Al Rayah El Monoufy for other samples the values fluctuated between 65 to $75 \%$ DW.

The protein content of aquatic weeds can vary according to species, seasonal period and geographic area (Ratana-arporn and Anong Chirapart 2006 and Haroon, 2020a, 2020b). In the present investigation samples of $M$. spicatum from Al-Rayah El Tawofiky and Al Rayah El Monoufy attained their lowest protein values during summer and winter being $7.94 \pm 0.41$ and $7.38 \pm 1.23 \%$ DW respectively, however the highest values were detected in autumn being $10.25 \pm 2.46$ and $11.41 \pm 1.65 \% \mathrm{DW}$ for the two Rayahs respectively. In contrast samples of $C$. demersum from Al Rayah El Monoufy have the lowest protein content in summer season, but the highest one was detected in their autumn samples from Al-Rayah El Tawofiky $(6.50 \pm 0.040$ and $15.69 \pm 0.13 \%$ DW respectively). The total protein content in the studied macrophytes from the two Rayahs were observed to be highest among submerged macrophytes $C$. demersum and $M$. spicatum $(15.69 \pm 0.13$ and $11.41 \pm 1.65 \%$ DW respectively) from Al-Rayah El Tawofiky and Al Rayah El Monoufy respectively. The two floating macrophytes species were recorded at Al Rayah El Monoufy and their protein contents fluctuated between 79\%.The results of the present study are comparable to those reported by Haroon (2008) and Haroon (2020 b), lower than that reported by Haroon (2010) and Abdel Shafy $\boldsymbol{e t}$ al. (2016) for different macrophytes species. This may be related to plant species, the part of plant used, time and place of samples collection. 


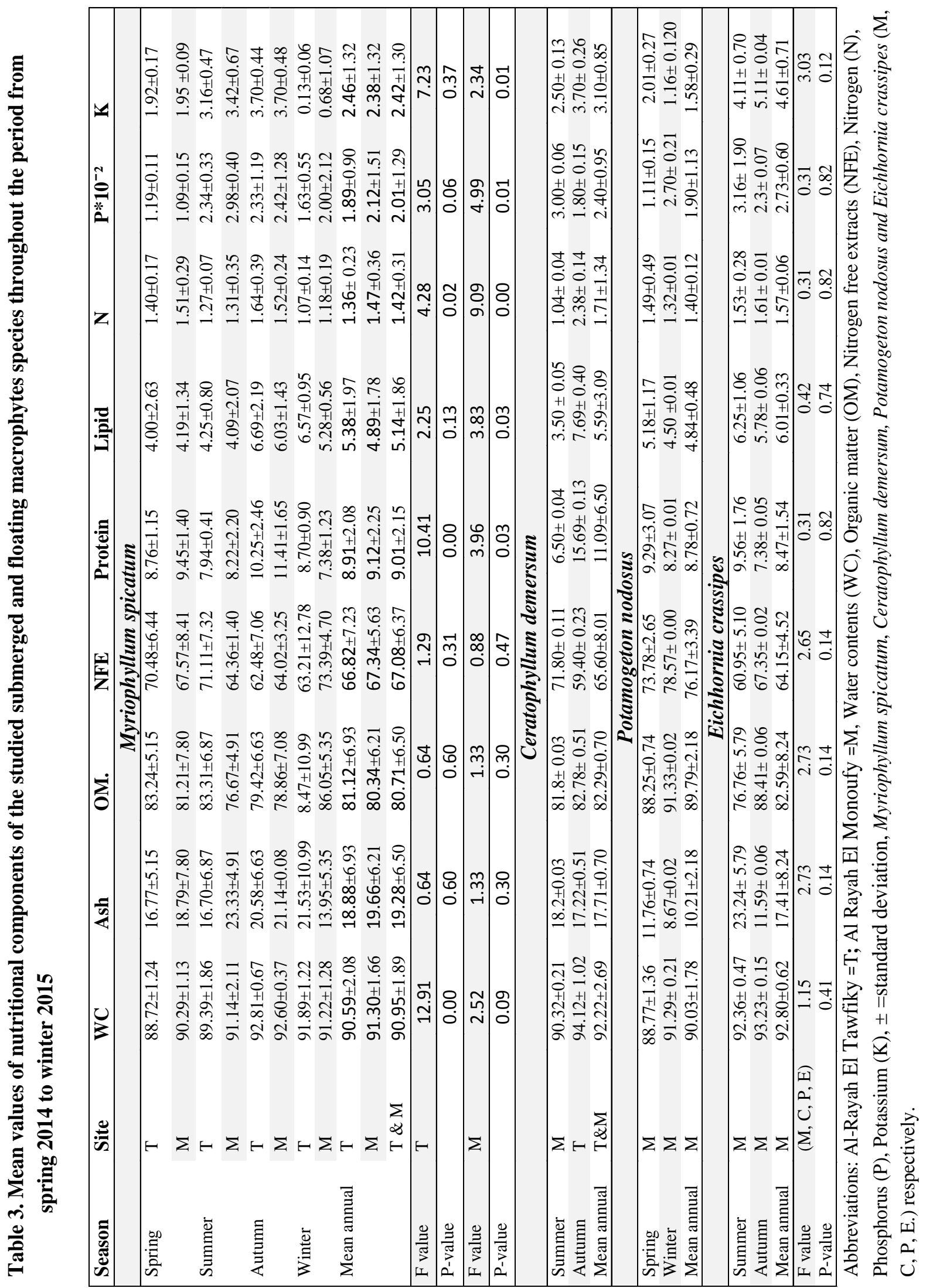


Aquatic plants were recorded to contain in percent dry weight from 1.18 to $5.42 \%$ of total lipid content (Boyd, 1968). Most of the submerged plants contained less than 4 percent lipid, although there were some exceptions, particularly for oxygen weed. As shown in (Table 3) plant lipids presented highest variations among the studied species, season and sampling site. Among the analyzed macrophytes species, the two submerged species recorded their highest lipid contents in autumn samples from Al-Rayah El Tawofiky being $6.69 \pm 2.19$ and $7.69 \pm 0.40 \%$ DW for $M$. spicatum and $C$. demersum respectively. These differences indicate an acceleration of productive metabolic activity during this period and/or higher consumption of this organic compound during the dry period (Haroon et al. 2000). The significant increases in the lipid content (about 5 times) were previously reported for C. demersum in the rainy season (Esteves and Suzuki 2010), Potamogeton pectinatus L. (Haroon, 2008) and for Myriophyllum spicatum (Haroon, 2014). In contrast, the two floating macrophytes species were found to be rich in their lipid contents during hot seasons (spring and summer) (Table 3).

Like other components, the values of macro-elements varied significantly $(\mathrm{p}<$ 0.05) between different species, sampling sites and seasons (Table 3). As previously recorded by Haroon (2008) N, P, and K are very important elements for plant cell as they are inter in protein, fatty acid synthesis and participate in the formation of many enzymes that is important for the chemical reactions inside plant cells, which make their concentrations being affected by plant growth form. This is coming in accord with the present results, where, the three macrophytes species $M$. spicatum, $C$. demersum and $E$. crassipes recorded their highest content of nitrogen $(1.64 \pm 0.39,2.38 \pm 0.14$ and $1.61 \pm$ $0.01 \%$ DW) and K (3.70 $\pm 0.44,3.70 \pm 0.26$ and 5.11 $0.04 \% \mathrm{DW})$ during autumn (the week growth period), at the same time the highest potassium contents $(2.98 \pm 0.40,3.00 \pm$ 0.06 and ${ }^{1} .17 \pm 1.90 * 10^{-2} \% \mathrm{DW}$ for the three species respectively) were detected in summer. Regarding, the free floating macrophyte species $P$. nodosus the highest $\mathrm{N}$ and $\mathrm{K}$ content (1.49 \pm 0.49 and $2.01 \pm 0.27 \%$ DW respectively) were detected during spring.

\section{Bacteriological analyses}

Fluctuations in the populations of total bacterial counts developed on either 20 or $35^{\circ} \mathrm{C}$, presented in Figure (2). ANOVA analysis indicated significant differences attributed to the seasons and the sites. In both canal, total bacteria developed on either 20 or $35{ }^{0} \mathrm{C}$ were particularly higher in autumn (up to $10^{5} \mathrm{cfu} \mathrm{ml}^{-1}$ ) and lower values were recorded in winter compared to other seasons. Among sites, in Al Rayah El Tawfiky the higher count developed on $20{ }^{0} \mathrm{C}$ were $1.5 \times 10^{5} \mathrm{cfu} / \mathrm{ml}$ at Site four (There are agricultural and residential regions at the two banks) in Summer which covered by the Submerged macrophytes, Myriophyllum spicatum, and emergent macrophytes, Saccharum spontaneum. While, in Al Rayah El Monoufy the third site (Shebeen El-Koum City) (unvegetated Sites) gave the lowest value at $20{ }^{\circ} \mathrm{C}$ or $35^{\circ} \mathrm{C}$ in winter. However, Reitner et al. (1999) recorded lower bacterial numbers in unvegetated areas compared to vegetated areas covered by the emergent macrophyte, Phragmites australis, it is likely that the specific composition of macrophytes may play a role in determining the net effect on bacteria. The bacterial metabolism is constrained by the carbon quality available in the macrophyte-dominated zone (They and Marques 2019). Wu et al. 2007, demonstrated that macrophytes may exert direct and indirect influences on the abundance and composition of bacterial communities. 


\section{Seasons*Sites (AL-Rayah El Tawfiky); LS Means}

Wilks lambda $=.00044, \mathrm{~F}(42,62)=69.238, \mathrm{p}=0.0000$

Effective hy pothesis decomposition

Vertical bars denote 0.95 confidence intervals

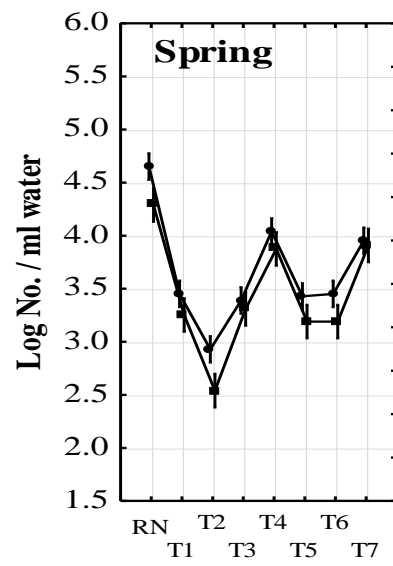

Sites

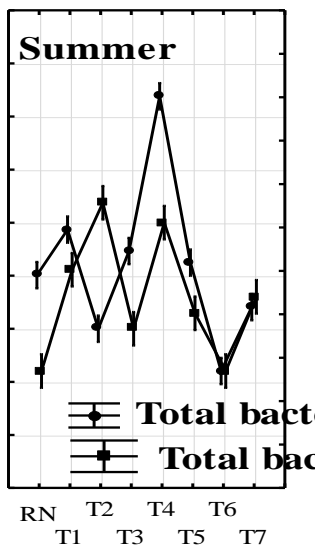

Sites

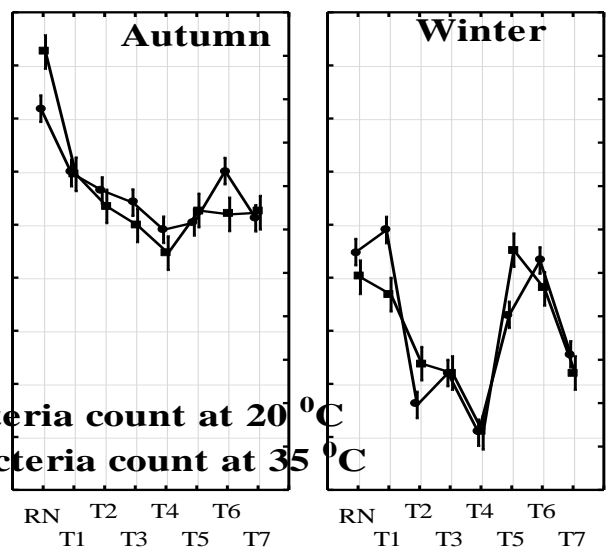

Sites

Sites

Seasons*Sites (Al-Rayah El-Monoufy); LS Means

Wilks lambda $=.00032, \mathrm{~F}(42,62)=81.095, \mathrm{p}=0.0000$

Effective hy pothesis decomposition

Vertical bars denote 0.95 confidence intervals
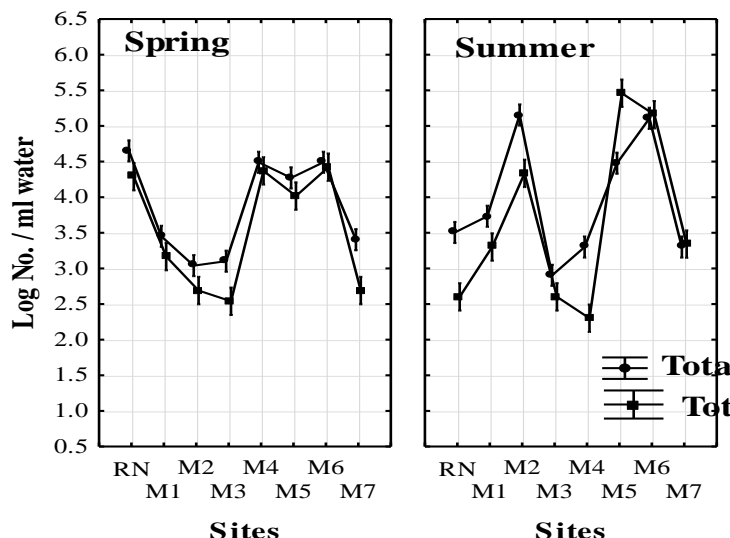

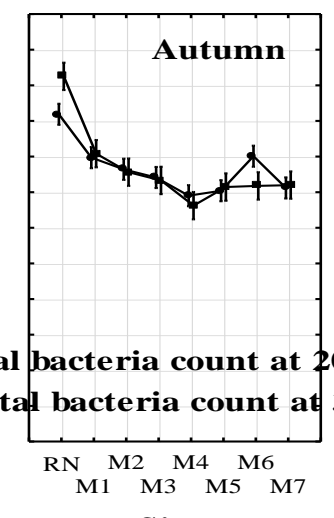

Sites

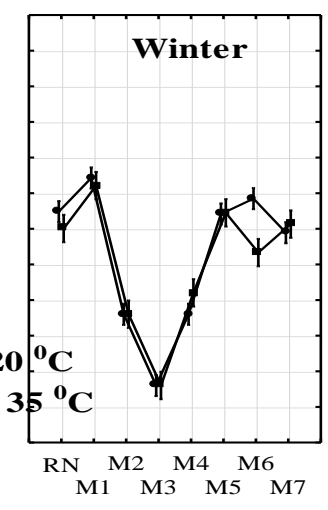

Sites

Fig. 2. Spatial and seasonal changes in microbial populations obtained of Al-Rayah El Tawfiky and Al Rayah El Monoufy water samples during the period of spring 2014 to winter 2015 (ANOVA analysis). 
The most pathogenic microorganisms responsible for waterborne diseases were originated from a fecal-oral transmission route. Therefore, fecal coli bacteria (FC) are frequently investigated in determining the hygienic quality of water as they present in human and animal feces (El-Aassar et al. 2018).

Most probable number (MPN) of indicator bacteria that obtained from Al Rayah El Tawfiky ranged from 90 to $12 \times 10^{3}, 3$ to 930 and 70 to $11 \times 10^{3} \mathrm{MPN} / 100 \mathrm{ml}$ for total coliforms, fecal coliforms and fecal strepotocci, respectively. Particular enrichment of total coliforms was distinguished at the spring season. Results of indicator bacteria ranged in Al Rayah El Monoufy from 90 to $12 \times 10^{3}, 4$ to $46 \times 10^{3}$ and 70 to $12 \times 10^{3}$ MPN/100 $\mathrm{ml}$ for total coliforms, fecal coliforms and fecal strepotocci, respectively. ANOVA analysis indicated significant differences attributed to the seasons (Figure 3). In spring season, site one of M1 (Behind fish research station of NIOF) which covered by floating macrophytes Potamogeton nodosus (according to Principal Component Analysis shows positive correlation between this plant and $\mathrm{FC}, \mathrm{r}=0.943, \mathrm{n}=4, \mathrm{p}<0.05$ ) and site M6 (In El Mahalla City) which covered also by the floating macrophytes Potamogeton nodosus, and submerged macrophytes Myriophyllum spicatum, recorded very high fecal coliform number (1500 MPN /100 ml and $4600 \mathrm{MPN} / 100 \mathrm{ml}$ respectively) which exceeds the recommended level in irrigation water and so it was not suitable to irrigation of any plants or trees. According to WHO Guide (WHO, 2011), the recommended level for irrigation of vegetables likely to be eaten uncooked was $200 \mathrm{MPN} / 100 \mathrm{ml}$ and irrigation of ornamental fruit trees and fodder crops was1000 MPN /100ml.

Fecal indicator bacteria such as total coliform, fecal coliform and streptococci are utilized worldwide to measure health hazards, their presence warns of the potential presence of disease causing organisms and should alert the person responsible for the water to take precautionary action (Sanders et al. 2005). Sites of Al Rayah El-Tawfiky recorded lo nn wer count of FC and within the permissible limit except sites T6 in spring and winter (420 MPN /100 ml and $930 \mathrm{MPN} / 100 \mathrm{ml}$ respectively), which covered with submerged macrophytes, Myriophyllum spicatum in both seasons. The elevated fecal coliform densities may be due to increased nutrient availability as well as protection from UV radiation that are provided by vegetation that act as a secondary habitat for fecal indicator bacteria (E. coli) (Jang et al. 2017 and Mathai 2019). In addition, the presence of submerged plants in water sources increase the bed and bank roughness, that results in increasing drag, decreasing flow rate and increasing eutrophication of water (Narasimha and Benarjee, 2016).

El-Meihy (2018), found the counts mean of total coliform (TC) were ranged between $\left(51 \times 10^{2}-27 \times 10^{4} \mathrm{CFU} / 100 \mathrm{ml}\right)$ in water samples collected from Rosetta branch during winter and summer. While in Damietta Branch waters were ranged between 29 - 8000 and $24-930 / 100 \mathrm{ml}$ water for TC and FC, respectively. On the other hand, the most probable number of FS varied from 14 to $2900 / 100 \mathrm{ml}$ water. MHE (1996) and EC (1998) accepted the guide values of recreational water up to 500/100 ml water for TC and 100/100ml water for FC and FS (Khalifa and Sabae, 2012). WHO considers a water sample non-potable if one or more $E$. coli are present in the water sample. WHO also classifies drinking water into five risk categories according to the $E$. coli count per $100 \mathrm{ml}$ of water sample:(in conformity with WHO guidelines), 1-10 (low risk), 10-100 (intermediate risk), 100-1000 (high risk), >1000 (very high risk) (WHO 2011). 
Seasons (AL-Rayah El-Tawfiky); LS Means

Wilks lambda $=.15813, \mathrm{~F}(9,141.31)=17.799, \mathrm{p}=0.0000$

Effective hy pothesis decomposition

Vertical bars denote 0.95 confidence intervals

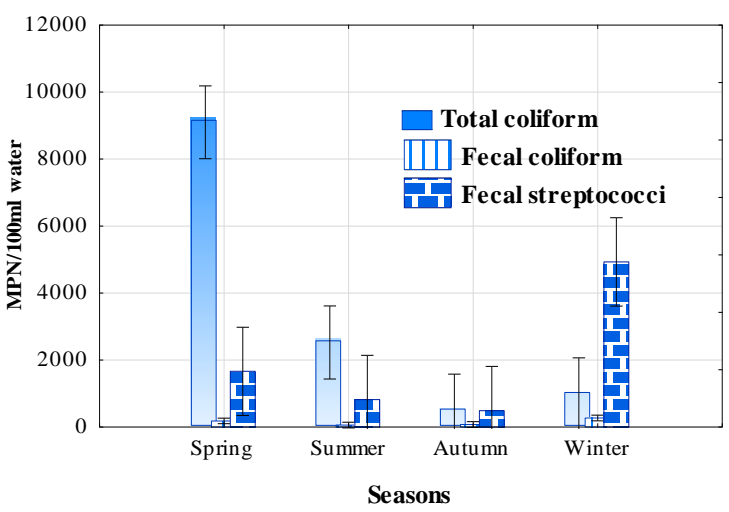

Seasons (Al-Rayah El-Monoufy); LS Means

Wilks lambda $=.46767, F(9,141.31)=5.7547, p=.00000$

Effective hypothesis decomposition

Vertical bars denote 0.95 confidence intervals

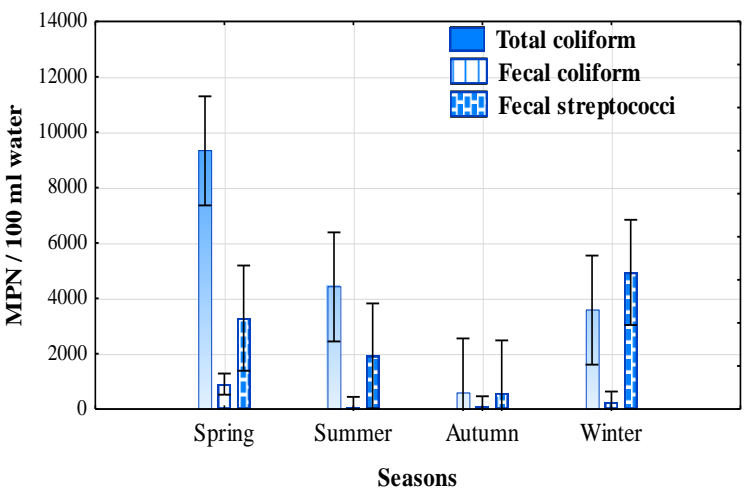

Sites (AL-Rayah E-Tawfiky); LS Means

Wilks lambda $=.45728, F(21,155.61)=2.3211, \mathrm{p}=.00178$

Effective hypothesis decomposition

Vertical bars denote 0.95 confidence intervals

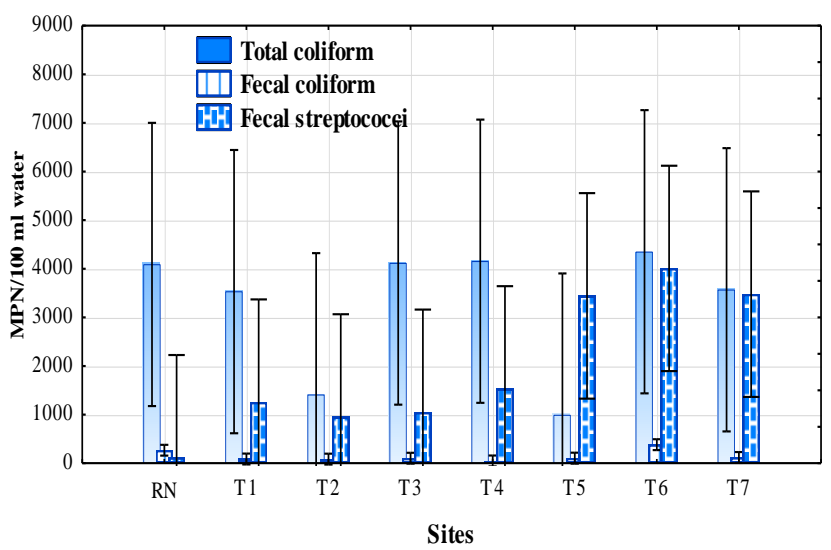

Sites (Al-Rayah El-Monoufy); LS Means

Wilks lambda $=.55101, F(21,155.61)=1.7093$, $\mathrm{p}=.03438$

Effective hypothesis decomposition

Vertical bars denote 0.95 confidence intervals

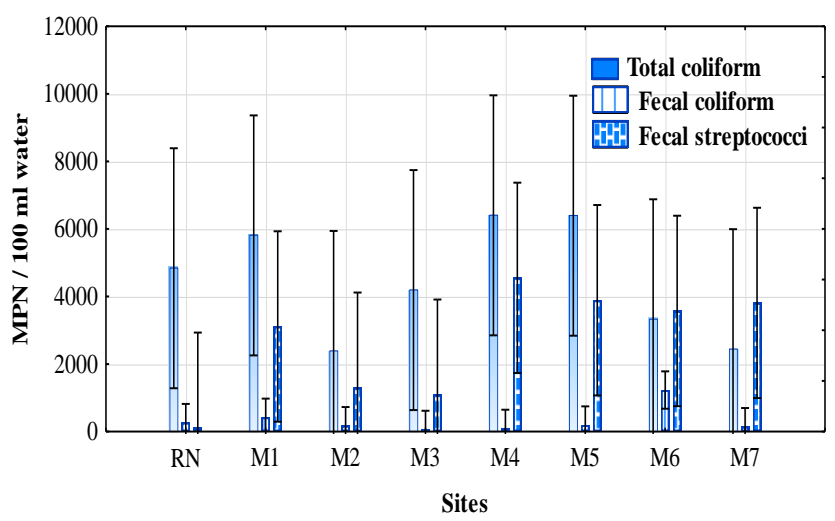

Fig. 3. Combined statistical analysis of bacterial indicators of pollution along the sites of Al Rayah El

Tawfiky and Al Rayah El Monoufy water samples during the period of spring 2014 to winter 2015

Fecal coliform can be influenced by land use and increased animal-agriculture system (Pandey $\boldsymbol{e t}$ al. 2014). In general, livestock and manure application as a fertilizer are reported to be main factors influencing bacterial contamination in agricultural streams. For example, the most contaminated bed sediment was observed in stream with unrestricted cattle access (Bragina et al. 2017). 
Similar to fecal coli bacteria, fecal streptococci are considered as indicators of water pollution and have been used for many years to determine the quality of water for irrigation and human consumption (WHO 1989 and Balkhair 2016). Seasonal fluctuations were significant for all indicators $(\mathrm{P}<0.05)$, with the highest count for fecal streptococci were found in winter season in the two canals. The higher flow rates and rainfall during the winter season may be led to higher bacteria counts because of increasing run-off from the informal settlement or re-suspension of bacteria from the river (Benhalima et al. 2018). Count of fecal strepotocci increased with the increase of Al-Rayah El- Tawfiky course (Figure 3). The increase in FS count may be explained by the introduction of more bacteria by human activities, agricultural, and livestock. Sampling sites are located near agricultural land.

Geldreich and Kenner (1969) suggested that the FC/FS ratio is characteristic for given types of pollution or sources of pollution. The ratio itself is not a quantitative indication of pollution but a qualitative pollution index. Thus, domestic sewage yields FC-FS ratios greater than 4.0, whereas ratios less than 0.7 indicate that the pollution derives from warm-blooded animals other than humans. The low ratios were reported in majority of sample for the two Rayahs indicating the non-human source of pollution except few sites such as M6 in spring season. In the rural areas most of populations have no access to sewer systems or using individual septic tank so, untreated sewage will be released into rivers and this can contributed for fecal contamination (Al-Badaii and Shuhaimi-Othman, 2015). Delta drains mainly used for discharge of poorly treated or untreated wastewater (domestic and industrial), and drainage of agricultural areas. Therefore, they contain high amounts of pollutants such as organic matter, nutrients, feacal coliform, heavy metals and pesticides (Emara et al. 2016 and El-Gohary, 2017).

The associative nitrogen-fixing bacteria (diazotrophs) were present in high population densities in the canals water $\left(\mathrm{Up}\right.$ to $10^{5}$ ) (Figure 4 ) a clear demonstration to the terrestrial supplement to the canals through agricultural drainage waters. ANOVA analysis indicated significant differences attributed to the seasons and sites. Diazotrophs play a vital role in aquatic system, not only as $\mathrm{N}_{2}$ fixer but also increase the aquatic productivity where diazotrophs can release growth factors beneficial for flora and fauna (Gonzalez-Bashan et al. 2000 and Othman et al. 2016).

Spring and winter seasons show low counts of diazotrophs compared to autumn and summer seasons. It is worth noting that the seasons with low populations of diazotrophs have few diversity of vegetation cover. Where one species (Myriophyllum spicatum) found in Al Rayah El- Tawfiky, and four species in Al Rayah El Monoufy (Myriophyllum spicatum, Potamogeton nodosus, Saccharum spontaneum, Echinochloa stagnina) in these seasons. Myriophyllum spicatum was found to spread in almost all sites of the canals. Anderson and Kalff (1986), found that the length and biomass of $M$. spicatum are increasing by addition of nitrogen. 

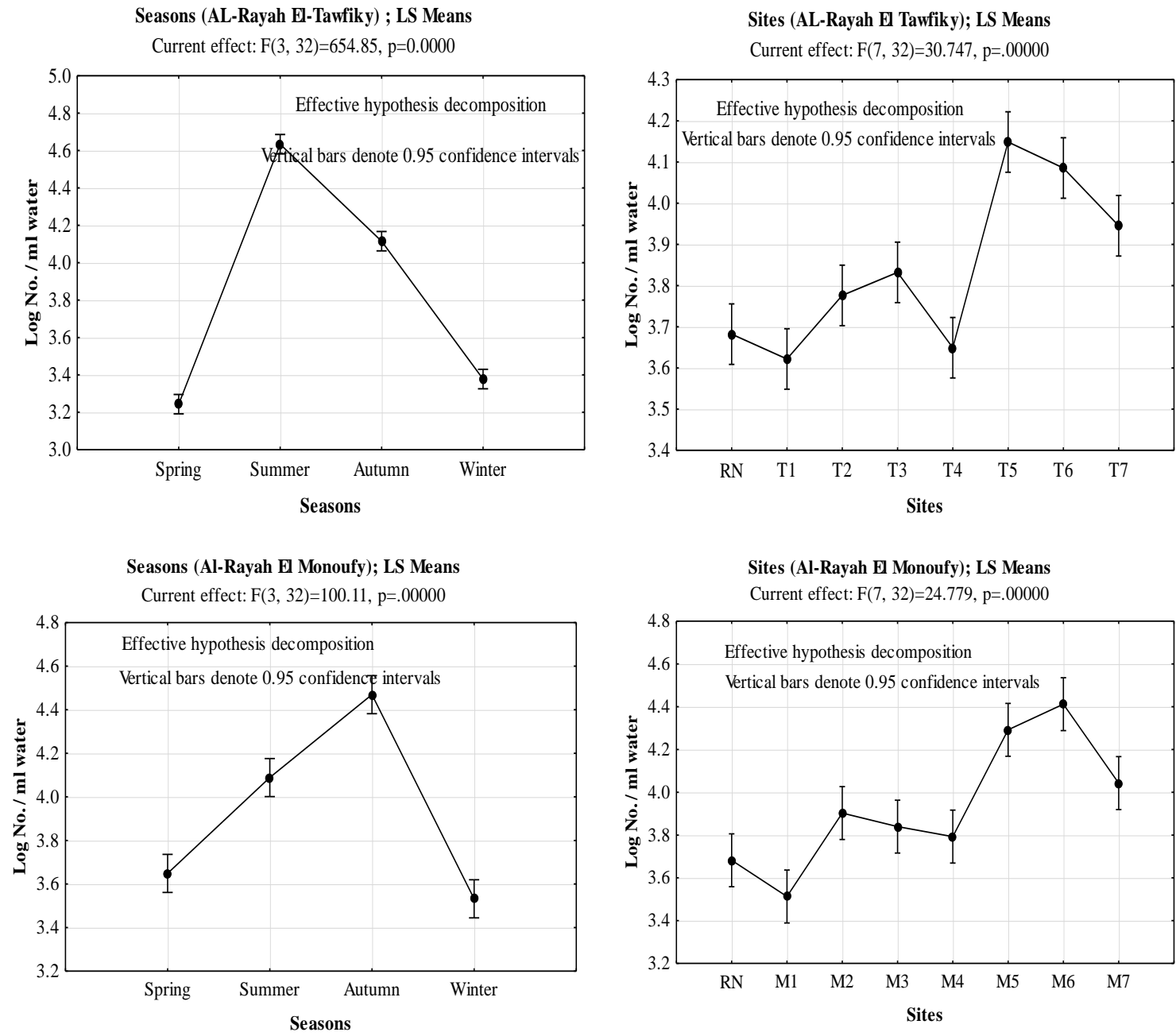

Fig. 4. Spatial and seasonal changes in nitrogen fixing bacteria densities of Al-Rayah El Tawfiky and Al Rayah El Monoufy water samples during the period of spring 2014 to winter 2015 (ANOVA analysis).

\section{Relation between macrophytes, bacteria and water parameters}

Different relations between different macrophytes species and the different ecological factors was observed (Figure 5). At Al-Rayah El Tawfiky the distribution of the two submerged macrophytes species Myriophyllum spicatum and Ceratophyllum demersum show negative but non significance correlation with presence of free floating species E. crassipes, which may be attributed partially to the shade caused by this plants, that affect light penetration and lower availability of atmospheric oxygen and carbon dioxide (Sastroutomo, 1985). The same trend of correlation was observed between Eichhornia crassipes and the three emergent macrophytes species Echinochloa stagnina, Cyperus alopecuroides and Polygonum tomentosum that explain the absence of this plant species from sites occupied by these species. Ceratophyllum demersum was significantly correlated with the emergent species Echinochloa stagnina and Cyperus alopecuroides $(\mathrm{r}$ $=1$ at $\mathrm{P}<0.05)$. In addition a strong positive relations between Saccharum spontaneum and Phragmites australis $(\mathrm{r}=0.985$ at $\mathrm{P}<0.05)$ and between Echinochloa stagnina, 
C. alopecuroides and Polygonum tomentosum $(\mathrm{r}=1$ at $\mathrm{P}<0.05)$ were detected. Similar relations were recorded by Shaltout et al. (2009) and Haroon and Hussian (2017).

In contrast at Al Rayah El Monoufy the free floating species E. crassipes was positively correlated with the three emergent macrophytes species Saccharum spontaneum, Cyperus alopecuroides and Polygonum tomentosum ( $\mathrm{r}=$ 0.943, 1.00 and 0.870 at $\mathrm{P}<0.05)$. Ceratophyllum demersum showed negative but non significance relation with Potamogeton nodosus and Echinochloa stagnina, however it have a significance positive relation with Polygonum tomentosum $(\mathrm{r}=1.00$ at $\mathrm{P}<0.05)$, This variation could be related to the different environmental factors as well as the allelophatic interaction between different macrophytes species and other aquatic organisms, beside human impact and effect of grazing animals. The distribution and abundance of aquatic macrophyte were found to be affected by water and sediment characteristics (Alahuhta $\boldsymbol{e t}$ al. 2012; Hussian and Haroon 2019 and Haroon, 2020b). This is coming in accord with the present study, where the distribution of most recorded macrophytes species was negatively correlated with water $\mathrm{DO}, \mathrm{COD}, \mathrm{BOD}, \mathrm{PO}_{4}$ and positively correlated with water $\mathrm{NO}_{2}, \mathrm{NO}_{3}$, Temp, and $\mathrm{pH}$ values.

Simple linear correlation coefficient showed a significant different relations between some water characteristics and macrophytes biochemical composition except for plant lipids. In the two studied Rayahs water temperature was positively correlated with plant potassium $(\mathrm{K})$ at $\mathrm{P}<0.05, \mathrm{P}<0.01$ ( $\mathrm{r}=0.545$ and 0.457 respectively). For samples from Al Rayah El-Tawfiky PH value was positively correlated with protein, NFE, N and phosphorus at $\mathrm{P}<0.05$ ( $\mathrm{r}=0.401,0.351,0.421$ and 0.394 respectively) while it was correlated with $\mathrm{K}$ at $\mathrm{P}<0.01, \mathrm{r}=0.568$, however $\mathrm{DO}$ was only correlated with $\mathrm{K}$ at $\mathrm{P}<$ $0.01, \mathrm{r}=-0.528$. However, $\mathrm{NO}_{2}$ was positively correlated with $\mathrm{K}(\mathrm{r}=0.389 \mathrm{P}<0.05)$. Similar relation was observed between $\mathrm{NO}_{3}$ and protein and $\mathrm{K}(\mathrm{r}=0.388$ and 0.417 at $\mathrm{P}<$ 0.05 respectively). For samples from Al Rayah El Monoufy, $\mathrm{pH}$ was positively correlated with phosphorus, DO and BOD were negatively correlated with $\mathrm{K}$ at $\mathrm{P}<0.05$. Some researcher like Rather and Nazir (2015); Haroon et al. (2018); Haroon (2020a, 2020b) confirmed the relation between water nutrients and plant components however other researcher (Nichols and Keeney, 1976 and Tucker and Debusk, 1981) mentioned the absence of this relation.

Different relations were also detected among different bacterial groups, plants components and chemical water parameters, for example at Al-Rayah El Tawofiky, TBC at $20^{\circ} \mathrm{C}$ was significant correlated with plant $\mathrm{K}$ content $(\mathrm{r}=0.494 \mathrm{n}=28$ at $\mathrm{P}<0.05)$, while $\mathrm{TBC}$ at $35^{\circ} \mathrm{C}$ was significant correlated with plant $\mathrm{N}$, lipid, ash water content, $\mathrm{NO}_{2}$ and $\mathrm{NO}_{3}(\mathrm{r}=0.415,0.445,0.414,0.376,0.385,0.383$ respectively $\mathrm{n}=28$ at $\mathrm{P}<0.05)$ and with protein and potassium ( 0.485 and 0.583 respectively $\mathrm{n}=28$ at $\mathrm{P}<0.01)$, also fecal strepotocci was significant correlated with BOD $(r=0.469 \mathrm{n}=28$ at $\mathrm{P}<0.05)$. At AlRayah El Monoufy, total diazotrophs was significant correlated with DO ( $\mathrm{r}=-0.451, \mathrm{n}=28$ at $\mathrm{P}<0.05)$ fecal streptococci was only correlated with plant lipids $(\mathrm{r}=0.367, \mathrm{n}=28$ at $\mathrm{P}<$ $0.05), \mathrm{TBC}$ at $20^{\circ} \mathrm{C}$ and Total coliform was negatively correlated with lipid and phosphorus ( $\mathrm{r}=-0.329$ and $-0.349, \mathrm{n}=28$ at $\mathrm{P}<0.05$ respectively).

Principal Component Analysis (PCA) shows negative correlation between dissolved oxygen and total diazotrophs, in two canals ( $\mathrm{r}=0.584 \& 0.888, \mathrm{n}=4, \mathrm{p}<0.05)$, as expected due to this bacterial group is belong to a facultative anaerobic bacteria. While it 
shows significant positive correlation with Phragmites australis and Saccharum spontaneum $(\mathrm{r}=0.967 \& 0.959, \mathrm{n}=4, \mathrm{p}<0.05)$ in Al Rayah El Tawfiky (Figure 5).

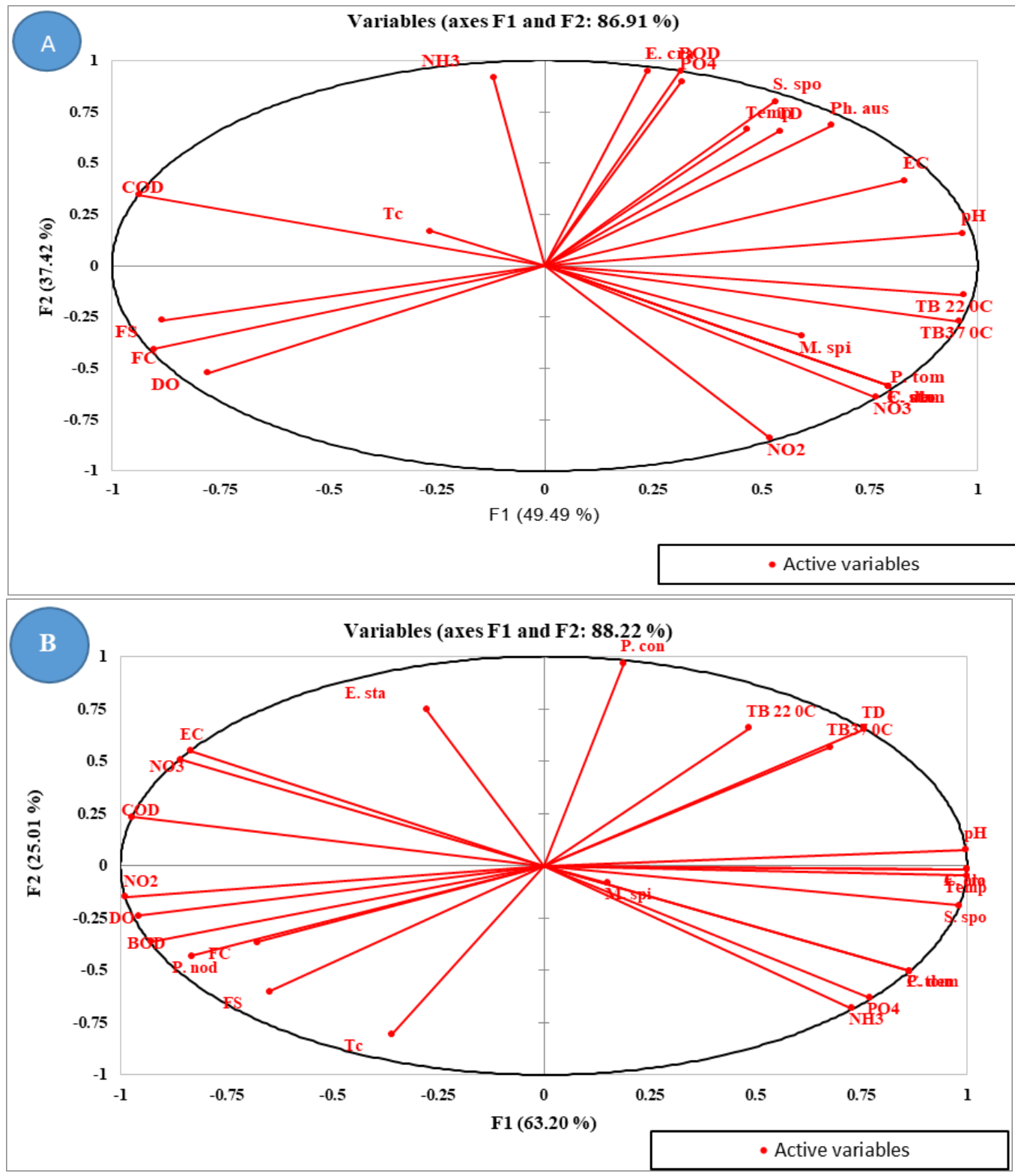

Fig. 5: The Principal Component Analysis (PCA) diagram of physicochemical parameters, macrophytes species and bacterial groups. (A) Al-Rayah El Tawfiky, (B) Al Rayah El Monoufy

Abbreviations: Myriophyllum spicatum L, (M. spi), Ceratophyllum demersum (C. dem), Potamogeton nodosus Poir, (P. nod), Eichhornia crassipes (Mart.) Solm (E. cra), Saccharum spontaneum (L.) (S. spo), Echinochloa stagnina (Retz.) P. Beauv. (Per) (E. sta), Polygonum tomentosum, (P. tom), Polygonum convolvulus L (P. con), Cyperus alopecuroides Rottb (Per) (C. ale), Phragmites australis (Cav.) Trin. (Ph. aus), total bacterial count (TB) at $22,37^{\circ} \mathrm{C}$, total coliform (TC), fecal coliform (FC), faecal streptococci (FS) Water temperature (Temp), Total nitrogen (TN), Total phosphorus $\left(\mathrm{PO}_{4}\right)$, Electrical conductivity (EC), Dissolved oxygen (DO), Biochemical oxygen demand (BOD), Chemical oxygen demand (COD), Nitrite $\left(\mathrm{NO}_{2}\right)$, Nitrate $\left(\mathrm{NO}_{3}\right)$ and Ammonium $\left(\mathrm{NH}_{4}\right)$. 


\section{CONCLUSION}

A significant differences in distribution, community structure and chemical composition of aquatic macrophytes and bacterial groups attributed to the seasons and sites differences was observed. In comparison, autumn season and sites of Al- Rayah El Monoufy were found to be the richest in species numbers. The submerged macrophyte species Myriophyllum spicatum was the most dominant and widely distributed species and Ceratophyllum demersum was the richest species in nutritional components. Bacterial analysis indicated the presence of indicator species of pollution in higher densities that exceeding the permissible limits cited by world health organization (WHO) especially at Al- Rayah El Monoufy. In addition, the results confirmed the nutritional potential of studied macrophyte species (especially submerged ones), beside their relation with different bacterial groups and different environmental variables that could be benefit in purposes of nutrition and water purification.

\section{ACKNOWLEDGMENT}

The present study was done in the framework of project plan of National Institute of Oceanography and Fisheries "The environmental status of the Nile Rayahs". The authors wish to express their sincere thanks to prof. Mohamed El-Sherif Goher, Head of Chemistry laboratory, National Institute of Oceanography and Fisheries, for providing chemicals data.

\section{REFERENCES}

Abdel Shafy, H. I.; Farid M. R. and Shams El-Din, A. M. (2016). Water-Hyacinth from Nile River: Chemical Contents, Nutrient Elements and Heavy Metals. Egypt. J. Chem. 59(2): 131- 143.

Alahuhta, J.; Kanninen, A. and Vuori K-M. (2012). Response of macrophyte communities and status metrics to natural gradients and land use in boreal lakes. Aquat Bot. 103:106-114. doi.org/10.1016/j.aquabot.2012.07.003.

Al-Badaii, F. and Shuhaimi-Othman, M. (2015). Water pollution and its impact on the prevalence of antibiotic-resistant $E$. coli and total coliform bacteria: a study of the Semenyih River, Peninsular Malaysia. Water Qual. Exp. Health, 7(3): 319330. doi.org/10.1007/s12403-014- 0151-5.

Anderson, M. R. and Kalff, J. (1986). Nutrient limitation of Myriophyllum spicatum growth in situ. Freshwater biology, 16 (6): 735-743. doi.org/10.1111/j.13652427.1986.tb01014.x

APHA, American Public Health Association. (2005). Standard Methods for the Examination of Water and Wastewater, $18^{\text {th }}$ ed. Washington, 1268pp.

Balkhair, K. S. (2016). Microbial contamination of vegetable crop and soil profile in arid regions under controlled application of domestic wastewater. Saudi j. boil. Sci., 23 (1): 83-92. doi.org/10.1016/j.sjbs.2015.10.029

Benhalima, L.; Kadri, S.; Barour, C.; Bensouilah, M. and Ouzrout, R. (2018). Water Quality Assessment of a Coastal Canal within a Protected Zone in Algeria using Principal Component Analysis. Indian J. Sci. Technol., 11 (31): 1-14 
doi: $10.17485 / \mathrm{Ijst} / 2018 / \mathrm{v} 11 \mathrm{i} 31 / 103479$

Black, C. A. (1965). Methods of soil analysis chemical and microbiological properties. (part 2) Amer. Soci. Agr. Inc

Blight, E.G. and Dyer, W. J. (1959). A Rapid Method of Total Lipids Extraction and Purification. Can. J. Biochem. Physiol., 37: 911-917. doi.org/10.1139/y59-099

Boyd, C. E. (1968). Fresh water plants: a potential source of protein. Econ. Bot 22 (4): 359-368.

Bragina, L.; Sherlock, O.; Van Rossum, A. J. and Jennings, E. (2017). Cattle exclusion using fencing reduces Escherichia coli (E. coli) level in stream sediment reservoirs in northeast Ireland. Agric. Ecosyst. Environ. 239: 349-358. doi:10.1016/j.agee.2017.01.021

Boulos, L. (2005). Flora of Egypt: (Monocotyledons), Vol 4. Al-Hadara Publishing, Cairo

Burgski, P. (1968). Handbook of agronomichemistry. Kolos Publishing House, Moscow. (In Russian), pp. 29-86.

Daboor, S. M. and Haroon, A. M. (2012). In vitro: Antimicrobial potential and phytochemical screening of some Egyptian aquatic plants. Egypt. J. Aquat Res., 38 (43): 233-239. doi.org/10.1016/j.ejar.2013.01.005

Del Pozo, R.; Fernandez-Alaez C. and Fernadez-Alaez M. (2011). The relative importance of natural and anthropogenic effects on community composition of aquatic macrophytes in Mediterranean ponds. Mar Freshw Res. 101-109. [Google Scholar] doi: 10.1038/srep36178

Edward, P. (1980). Food potential of aquatic macrophytes. ICLARM Studies and Reviews, 5, 51.

Egyptian Pharmacopoeia, (1953). Ist English Ed. Cairo Univ. Press, Cairo, U. A. R.

El-Amier, Y. A. and Al-Mamory, S. H. (2016). Macrophytic Vegetation-Environment Relationship along Rosetta Branch of the River Nile in Egypt. J. Environ. Sci., 45 (3-4): 299-314.

El-Amier, Y.A.; Zahran, M.A. and Al-Mamoori, S.O. (2015). Plant diversity of the Damietta Branch, River Nile, Egypt. Mesop. Environ. 1 (2): 109-129

El-Aassar, A. H. M.; Omer, A. M.; and Badawy, R. K. (2018). Assessment of environmental pollution and its impact on water resources, soils and crops in the area adjacent Bahr El-Bakr Drain, East-Delta, Egypt. Alex. Sci. Exchange J., 39: 124-143. doi: 10.21608/ASEJAIQJSAE.2018.5819

El-Gohary, R. (2017). Effect of increasing discharge on water quality: A case study. Asian Journal of Natural \& Applied Sciences. 6(2): 51-62. https://www.researchgate.net/publication/318945140

El-Meihy, R. M. (2018). Microbiological and physicochemical evaluation of River Nile (Rosetta branch). Annals of Agricultural Science, Moshtohor, 56 (4th ICBAA): 217-226. doi:10.21608/ASSJM.2018.65525

El-Sheekh, M. M.; Haroon, A. M. and Sabae, S. (2017). Activity of some Nile River aquatic macrophyte extracts against the cyanobacterium Microcystis aeruginosa. African J. Aquat. Sci., 42(3), 271-277.

doi.org/10.2989/16085914.2017.1358138

Emara, E. K. M.; Farfour, S.A. and Mousa I. E. (2016). Environmental Studies on the Effects of Aquaculture and Drainage Wastewaters on Lake Burullus. 
American-Eurasian J. Agric. \& Environ. Sci., 16 (2): 410-423. doi: 10.5829/idosi.aejaes.2016.16.2.102160

Esteves, B. D. S. and Suzuki, M. S. (2010). Limnological variables and nutritional content of submerged aquatic macrophytes in a tropical lagoon. Acta Limnol. Bras. 22 (2): 187-198. doi.org/10.4322/actalb.02202008

European Commission Guide Standard (EC). (1998). Quality of bathing water, 1997, Document EUR/18166, Brussels.

Goher, M. E. (2015). The environmental status of the Nile Rayahs, Egypt Final Report. National Institute of Oceanography and Fisheries (NIOF), Egypt (Under press).

Geldreich, E. E. and Kenner, B. A. (1969). Concepts of fecal streptococci in stream pollution. Journal (Water Pollution Control Federation), 41(8), R336-R352. WWW.jstor.org/stable/25036430

Gonzalez-Bashan, L. E.; Lebsky, V. K.; Hernandez, J. P.; Bustillos, J. J. and Bashan, Y. (2000). Changes in the metabolism of the microalga Chlorella vulgaris when coimmobilized in alginate with the nitrogen-fixing Phyllobacterium myrsinacearum. Can. J. microbial., 46 (7): 653-659. doi.org/10.1139/w00-041

Hansel-Welch, N.; Butler, M. G.; Carlson, T. J. and Hanson, M. A. (2003). Changes in macrophyte community structure in Lake Christina (Minnesota), a large shallow lake, following biomanipulation. Aquat. Bot. 75 (4): 323-337. doi.org/10.1016/S0304-3770(03)00002-0 [Google Scholar]

Haroon, A. M. (2008). Nutrition value and factors affecting the energy and biochemical composition of some macrophytes from Lake Manzalah (Egypt). Egypt. J. Aquat. Res. 34(4): 143-157.

Haroon, A. M. (2010). Evaluation of the nutritional status of Nymphaea lotus L. and Pistia stratiotes L. shoots in relation to their utilization as fish and animal feed. Egypt. J. Aquat Res., 36(4): 587-595.

Haroon, A. M. (2014). Long Term Changes of Macrophytes in Lake Nasser. 169-192. In El-shabrawy, G., 2014. Ecological basis for Lake Nasser ecosystem. Lambert Academic Publishing.

Haroon, A. M., (2020a). Proximate and Total Fatty Acid Composition of Some Aquatic Macrophytes in the Nile River Rayahs, Egypt. Pak. J. Biol. Sci. 23: 295305.doi.10.3923/pjbs.2020.295.305

Haroon, A. M., (2020b). Factors affecting community structure, distribution pattern and chemical composition of aquatic macrophytes in El-Rayah El-Nasery and ElNoubaria Canal of Nile River, Egypt, Egypt. J. Aquat Res., doi.org/10.1016/i.ejar.2020.05.002

Haroon, A. M. and Abdel-Aal, E. I. (2016). Chemical composition and in vitro antialgal activity of Potamogeton crispus and Myriophyllum spicatum extracts. Egypt. J. Aquat. Res., 42(4): 393-404. doi.org/10.1016/j.ejar.2016.12.002

Haroon, A. M. and Daboor, S. M. (2019). Nutritional status, antimicrobial and antibiofilm activity of Potamogeton nodosus Poir. Egypt. J. Aquat. Biolo. \& Fisheries. 23(2): 81-93. 10.21608/EJABF.2019.29301

Haroon, A. M. and Hussian, A. M. (2017). Ecological assessment of the macrophytes and phytoplankton in El-Rayah Al-Behery, River Nile, Egypt. Egypt. J. Aquat. Res., 43 (3): 195-203. doi.org/10.1016/j.ejar.2017.08.002 
Haroon, A. M.; Hussian, A. M. and El-Sayed, S. M. (2018). Deviations in the biochemical structure of some macroalgal species and their relation to the environmental conditions in Qarun Lake, Egypt. Egypt. J. Aquat. Res. Egypt. J. Aquat. Res. Egypt. J. Aquat. Res. Egypt. J. Aquat. Res. Egypt. J. Aquat. Res. Egypt. J. Aquat. Res. Egypt. J. Aquat. Res. Egypt. J. Aquat. Res., 44: 15-20. doi.org/10.1016/j.ejar.2018.02.006

Haroon, A. M.; Szaniawska, A.; Normant, M. and Janas, U. (2000). The biochemical composition of Enteromorpha spp. from the Gulf of Gdansk coast on the Southern Baltic Sea. Oceanologia 42 (1): 19-28.

Hegazi, N. A.; Hamza, M. A.; Osman, A. A.; Ali, S.; Sedik, M. Z. and Fayez, M. (1998). Modified combined carbon $\mathrm{N}$-deficient medium for isolation, enumeration and biomass production of diazotrophs. In: Malik Kauser A, Mirza M Sajjad and Ladha J.K., eds. $7^{\text {th }}$ International Symposium on Nitrogen Fixation with NonLegumes, 16-21October 1996, Faisalabad, Pakistan, Kluwer Academic Publishers, Dordrecht, pp. 247-253.

Hussian, A. M. and Haroon, A. M. (2019). Sensitivity of submerged aquatic macrophytes and their epiphytic microalgae to the different environmental variables in River Nile, Egypt. Int. J. Ecol. Environ. Sci., 45 (1): 107-122, 2019. ISSN: 2320-5199 (Online)

Jabir, T.; Vipindas, P. V.; Jesmi, Y.; Valliyodan, S.; Parambath, P. M.; Singh, A. and Abdulla, M. H. (2020). Nutrient stoichiometry (N: P) controls nitrogen fixation and distribution of diazotrophs in a tropical eutrophic estuary. Mar. Pollut. Bull., 151, 110799. doi.org/10.1016/i.marpolbul.2019.110799

Jang, J.; Hur, H. G.; Sadowsky, M. J.; Byappanahalli, M. N.; Yan, T. and Ishii, S. (2017). Environmental Escherichia coli: ecology and public health implicationsa review. J. Appl. Microbiol. 123: 570-581. doi.org/10.1111/jam.13468.

Khalifa, N. and Sabae, S. Z. (2012). Investigation on Mutual relations between bacteria and zooplankton in Damietta branch, River Nile, Egypt. J. Appl. Sci. Res., 8 (5): 2679-2688. https://www.researchgate.net/profile

Mathai, P. P.; Dunn, H. M.; Magnone, P.; Zhang, Q.; Ishii, S.; Chun, C. L. and Sadowsky, M. J. (2019). Association between submerged aquatic vegetation and elevated levels of Escherichia coli and potential bacterial pathogens in freshwater lakes. Sci. Total Environ., 657: 319-324. doi.org/10.1016/j.scitotenv.2018.11.484

Ministry of Health, Egypt, (1996). Microbiological standards of the Egyptian recreational waters, Report No. 64.

Narasimha, R. K. and Benarjee, G. (2016). Diversity and distribution of macrophytes in Nagaram tank of Warangal district, Telangana state. Int. J. Fisheries and Aquat. Stud., 4 (1): 270-275.

Nicols, D. and Keeney, D. R. (1976). Nitrogen nutrition of Myriophyllum spicatum: Uptake and translocation of $15 \mathrm{~N}$ by shoots and roots. J. Fresh Water Biol., 6: 145-154.

Ölberg, K. (1956). Factors affecting the nutritive value of range forage. Rangeland Ecology \& Management/ Journal of Range Management Archives, 9(5): 220-225.

Othman A. Amal and Sabae, S. Z. (2013). Monitoring of Microbial Load and Pollution in Ismailia Canal, River Nile, Egypt. J. Environ. Sci., Special Issue of The 
International Scientific Conference of Environmental Sciences. 21-22May (2013), 1: 315-332.

Othman, A. A.; Ali, S. M. and Abbas, M. T. (2016). Microbial Water Quality and Diazotrophic Bacteria Community in Lake Nasser Khors, Egypt. Res. J. Environ. Toxicol., 10:100-108. doi: 10.3923/rjet.2016.100.108

Pádua, M. D.; Fontoura, P. S. G. and Mathias, A. L. (2004). Chemical composition of Ulvaria oxysperma (Kützing) Bliding, Ulva lactuca (Linnaeus) and Ulva fascita (Delile). Brazil, Archi. Biol. \&Tech., 47 (1): 49-55. doi: 10.1590/S1516-89132004000100007

Pandey, P. K.; Kass, P. H.; Soupir, M. L.; Biswas, S. and Singh, V. P. (2014). Contamination of water resources by pathogenic bacteria. AMB Express 4:51. doi.org/10.1186/s13568-014-0051-x

Ratana-arporn, P. and Anong Chirapart, A. (2006). Nutritional Evaluation of Tropical Green Seaweeds Caulerpa lentillifera and Ulva reticulate. Kasetsart J. (Nat. Sci.) 40 (Suppl.): $75-83$.

Rather, Z. A. and Nazir, R. (2015). Biochemical Composition of Selected Macrophytes of Dal Lake, Kashmir Himalaya. J Ecosys Ecograph 5 (1): 158.

Reitner, B.; Herzig, A. and Herndl, G. J. (1999). Dynamics in bacterioplankton production in a shallow, temperate lake (Lake Neusiedl, Austria): evidence for dependence on macrophyte production rather on phytoplankton. Aquat. Microbial Ecology. 19(3): 245-254. doi.org/10.3354/ame019245.

Sanders, B. F.; Arega, F. and Sutula, M. (2005). Modeling the dry-weather tidal cycling of fecal indicator bacteria in surface waters of an intertidal wetland. Water Res., 39 (14): 3394-3408. doi.org/10.1016/j.watres.2005.06.004

SAS, (1985). SAS/STAT User's Guide, SAS Instruction Incorporation, Cary, NC, USA.

Sastroutomo, S. S. (1985). "The role of aquatic vegetation in the environment," in Proceedings of the ANBS Workshop on Ecology and Management of Aquatic Vegetation in the Tropics, Jakarta, Indonesia.

Senl, F. D and Snel, C. T. (1967): Colorimetric methods of analysis. P. Van Nostrand Company, Inc. 551-522. ISBN 10: 1114693812 ISBN 13: 9781114693814

Shaltout, K. H.; Galal, T. M. and El-Komi, T. M. (2009). Evaluation of the nutrient status of some hydrophytes in the water courses of Nile Delta, Egypt. J. Bot., 1-11 doi.org/10.1155/2009/862565

Sharshar, K. M. and Haroon, A. M. (2009): Comparative Investigation on Some Biological and Biochemical Aspects in Freshwater Caryfish (Procambarus calarkii) Fed on Eichhornia crassipes, Echinochloa stagnina L. and Polygonum tomentosum L. American Eurasian J. Agric. \& Environ. Sci., 5 (4): 579-589.

Srivastava, J. K., Chandra, H., Kalra, S. J., Mishra, P., Khan, H. and Yadav, P. (2017). Plant-microbe interaction in aquatic system and their role in the management of water quality: a review. Applied Water Science, 7(3): 1079-1090. doi: 10.1007/s13201-016-0415-2

StatSoft Inc. (2011). STATISTICA (data analysis software system), (Tulsa, USA).v 10. www.statsoft.com.

They, N. H. and Marques, D. D. M. (2019). The structuring role of macrophytes on plankton community composition and bacterial metabolism in a large subtropical shallow lake. Acta Limnologica Brasiliensia, 31. e19. 


\section{doi.org/10.1590/S2179-975X10017}

Tucker, C. S. and Debusk, T. A. (1981). Seasonal growth of Eichhornia crassipes (Mart.) solms: Relationship to protein, fiber, and available carbohydrate content. Aquatic Botany 11:137-141. doi: 10.1016/0304-3770(81)90055-3.

WHO (World Health Organization), (1989). Health guidelines for the use of wastewater in agriculture and aquaculture. Report of a WHO Scientific Group. Geneva, (Technical Report Series, No. 778).

WHO (World Health Organization), Geneva. (2011). "Guidelines for drinking-water quality." World Health Organization 216, 303-4.

Umoren, U. E., Essien, A. I., Ukorebi, B. A. and Essien, E. B. (2005). Chemical Evaluation of the Seeds of Milletia obanensis. Food Chemistry, 91 (2): 195-201. doi.org/10.1016/j.foodchem.2003.08.029

Zhang, S., Pang, S., Wang, P., Wang, C., Guo, C., et al., (2016). Responses of bacterial community structure and denitrifying bacteria in biofilm to submerged macrophytes and nitrate. Sci. Rep., 6 (36178). doi.org/10.1038/srep36178

Zhi, W., Yuan, L., Ji, G. and He, C. (2015). Enhanced long-term nitrogen removal and its quantitative molecular mechanism in tidal flow constructed wetlands. Environ. Sci. Tech. 49(7), 4575-4583. doi.org/10.1021/acs.est.5b00017

Wu X., Xi W., Ye W. and Yang H. (2007). Bacterial community composition of a shallow hypertrophic freshwater lake in China revealed by $16 \mathrm{~S}$ rRNA gene sequences. FEMS Microbiol. Ecol.61:85-96. doi.org/10.1111/j.1574-

\section{$\underline{6941.2007 .00326 . x}$}

